\title{
Expression of islet neogenesis-associated protein in islets of normal hamsters
}

\author{
L E Flores, M E García, M I Borelli, H Del Zotto, M E Alzugaray, \\ B Maiztegui and J J Gagliardino
} CENEXA - Centre of Experimental and Applied Endocrinology (UNLP-CONICET, PAHO/WHO Collaborating Centre), National University of La Plata
School of Medicine, La Plata, Argentina
(Requests for offprints should be addressed to J J Gagliardino, CENEXA (UNLP-CONICET), Facultad de Ciencias Médicas, UNLP, Calles 60 y 120,
1900 La Plata, Argentina; Email: gagliardino@infovia.com.ar)

\begin{abstract}
The aim of the present study was to test the possible presence and expression of islet neogenesis-associated protein (INGAP) in islet cells of normal adult hamsters.

Pancreata from normal male Syrian hamsters were removed to perform the following studies. (i) Western blot analysis using the cytosolic fraction from homogenates of isolated islets, exocrine tissue and whole pancreas, and rabbit INGAP-specific antibody. (ii) Immunohistochemical identification of INGAP-positive cells in fixed sections of intact pancreata, fresh and $72 \mathrm{~h}$ cultured islets (isolated by collagenase digestion), and smears of exocrine pancreatic cells, using the same INGAP-specific antibody and streptavidin-biotin complex. (iii) RT-PCR using total RNA extracted from isolated islets and from exocrine tissue as template, and a specific pair of primers. (iv) Control of the sequence of the PCR products.
\end{abstract}

INGAP protein was identified by Western blot in the cytosolic fraction of homogenates from fresh isolated islets, exocrine cells and whole fresh pancreas. INGAPimmunopositive cells were observed in duct, exocrine and islet cells in either fixed intact or digested pancreatic tissue. INGAP mRNA was identified in samples of total RNA from fresh and cultured isolated islets and from exocrine cells.

Our data demonstrate that INGAP is present and expressed in islets and in exocrine pancreatic cells of normal hamsters. The ubiquitous localization of INGAP suggests its possible role in the physiological process of islet growth and its protective effect upon streptozotocininduced diabetes.

Journal of Endocrinology (2003) 177, 243-248

\section{Introduction}

Several hormones, transcription and growth factors are involved in the control of islet development and growth (Edlund 2001). One of these factors, islet neogenesisassociated protein (INGAP), originally isolated from pancreata of normal hamsters with previous cellophane wrapping of the pancreas head $(\mathrm{CW})$, has been identified as part of a protein complex called ilotropin (Pittenger $e t$ al. 1992). The immunocytochemical presence of INGAP has been shown not only in hamsters, but also in the pancreas of normal foetal mice (Rafaeloff-Phail et al. 1998a), adult rats (H Del Zotto \& C Semakula, unpublished observations), and in human beings (Rafaeloff-Phail et al. 1998b, Semakula et al. 2002). It has further been reported that INGAP administration to streptozotocin-treated hamsters decreased significantly the percentage of diabetic animals (Rafaeloff et al. 1997, Gold et al. 1998).

Using quantitative immunocytochemical techniques we have identified INGAP in pancreata from normal hamsters, and a significant increase of this peptide in hamsters with an insulin-resistant state induced by the administration of a sucrose-rich diet (Del Zotto et al. 2000). In all cases INGAP protein was detected in cells from the three pancreas subsectors, but mainly in islet non- $\beta$-cells. Most islet INGAP-positive cells did not co-stain with antibodies against any of the hormones expressed in the islets, while around $40 \%$ of them co-stained with a glucagon antibody (Del Zotto et al. 2000). However, Raffaelof et al. (1997) reported that INGAP was only expressed in the exocrine sector of the CW pancreas.

On account of these apparent discrepancies, we have currently studied the presence of INGAP protein (immunocytochemistry and Western blot analysis) and its gene expression (RT-PCR) in isolated islets and in exocrine cells isolated from adult normal hamsters. Our results demonstrate that INGAP is not only present and expressed in exocrine cells, but also in islet cells. 


\section{Materials and Methods}

\section{Animals and pancreas digestion}

Normal male Syrian hamsters from the Eppley colony (8 weeks of age, $80-100 \mathrm{~g}$ body weight; Omaha, NE, USA) were used. They were maintained in a room at $21 \pm 1{ }^{\circ} \mathrm{C}$ and $50 \pm 5 \%$ humidity, with a $12 \mathrm{~h}$ light: $12 \mathrm{~h}$ darkness cycle, and freely fed a commercial diet and tap water. Animals were killed by cervical dislocation and the entire pancreas was removed and digested (collagenase) to isolate islets and exocrine tissue (Lacy \& Kostianovsky 1967). For that purpose, removed pancreata were rinsed in KrebsRinger bicarbonate (KRB) buffer, cut into small pieces, and further incubated in the presence of collagenase; when islets were free of exocrine tissue (sequential observation under a stereomicroscope), the reaction was stopped by adding cold KRB. Islets were picked up one-by-one with capillary pipettes. Islet-free exocrine tissue was collected when all islets were removed from the digested pancreas.

\section{Islet cultures}

Groups of 50 islets were cultured for $24 \mathrm{~h}$ at $37^{\circ} \mathrm{C}$ in RPMI 1640 (Gibco-BRL, Grand Island, NY, USA), pH $7 \cdot 4$, containing $10 \%(\mathrm{v} / \mathrm{v})$ foetal calf serum and $4 \mathrm{mM}$ glucose in a humid atmosphere $\left(5 \% \mathrm{CO}_{2} / 95 \% \mathrm{O}_{2}\right)$. After $24 \mathrm{~h}$ of culture the medium was removed and the islets were cultured for another $48 \mathrm{~h}$ in the same medium.

\section{Western blotting}

Isolated islets and exocrine tissue cells obtained by collagenase digestion (Lacy \& Kostianovsky 1967) and whole pancreata were homogenized in $10 \mathrm{mM}$ Tris- $\mathrm{HCl}, \mathrm{pH}$ $7 \cdot 4$, with protease inhibitors $(4 \mu \mathrm{g}$ aprotinin; $0 \cdot 1 \mathrm{mM}$ benzamidine, and $0.1 \mathrm{mM}$ phenyl-methyl-sulphonyl fluoride). The homogenates were then centrifuged at $5300 \mathrm{~g}$ for $15 \mathrm{~min}$, and the supernatant was further centrifuged at $109000 \boldsymbol{g}$ for $90 \mathrm{~min}$. Protein concentration was measured in the supernatant by the method of Bradford (BioRad, Hercules, CA, USA). Both $10 \mu \mathrm{g}$ of protein from isolated islets and $5 \mu \mathrm{g}$ of protein from exocrine tissue cells or from whole pancreas homogenates were placed into the wells of the stacking gel containing $4 \%$ acrylamide, $125 \mathrm{mM}$ Tris- $\mathrm{HCl}, \mathrm{pH} 6 \cdot 8,0 \cdot 1 \%$ SDS, $0.05 \%$ ammonium persulphate and $0 \cdot 2 \% \quad N, N, N^{\prime}, N^{\prime}-$ tetramethylethylenediamine (TEMED). The running gel composition was $7 \cdot 5 \%$ acrylamide, $375 \mathrm{mM}$ Tris $-\mathrm{HCl}$, $\mathrm{pH} 8 \cdot 8,0 \cdot 1 \%$ SDS, $0 \cdot 2 \%$ ammonium persulphate, and $0 \cdot 2 \%$ TEMED. The reservoir buffer contained $0.025 \mathrm{M}$ Tris, $0 \cdot 192 \mathrm{M}$ glycine and $0 \cdot 1 \%$ SDS. In all cases Kaleidoscope polypeptide prestained standards (BioRad) were used as molecular mass markers. The gels were placed at room temperature and samples run at $60 \mathrm{~V}$ until they entered the gel; then, the voltage was increased up to $100 \mathrm{~V}$ until the front was about $0.5 \mathrm{~cm}$ from the bottom. The gels were then electroblotted onto a poly (vinylidene difluoride) microporous membrane (Immobilon, Millipore) by means of a discontinuous buffer system. Before immunostaining, the Immobilon sheets were treated with blocking solution and then incubated with appropriate dilutions of the primary specific antibody against INGAP (rabbit antibody IgG 1246, 1:1500; kindly provided by Dr Gerald Gold, Eli Lilly Company, Indianapolis, IN, USA) in PBS at room temperature for $1 \mathrm{~h}$. The specificity of this antibody has been previously tested (Rafaeloff-Phail et al. 1998a,b). Saturating antibody concentrations were used for all the immunostaining. After rinsing with $\mathrm{PBS}$, the streptavidin-peroxidase conjugate anti-rabbit IgG (Sigma Co., St Louis, MO, USA) was added for $1 \mathrm{~h}$; this step was followed by rinsing. Colour development was obtained using 3,3'-diamino-benzidine (DAB) (Sigma).

\section{Immunohistochemical studies}

Pancreata were fixed in Bouin's liquid and embedded in paraffin. Thin sections $(5 \mu \mathrm{m})$ were mounted on silanized (3-amino-propyltriethoxy-silane; Sigma) slides. Immunocytochemical identification of INGAP-positive cells was performed in deparaffinized sections treated with normal porcine serum $(30 \mathrm{~min})$ to reduce non-specific staining, and with methanol-hydrogen peroxide $(30 \mathrm{~min})$ to block endogenous peroxidase. The slides were incubated for $24 \mathrm{~h}$ at $4{ }^{\circ} \mathrm{C}$ in a humidified chamber, with appropriately diluted rabbit INGAP-specific antibody (IgG 1246, 1:600), or normal rabbit serum. The final staining was performed using 30 min incubations with the streptavidinbiotin complex or alkaline phosphatase (Sigma, 1:40 and 1:20 respectively) and revealed with carbazole, DAB or fast blue.

\section{Islet immunohistochemistry}

Five hundred isolated islets were fixed in Bouin's liquid and embedded in paraffin. Thin sections $(5 \mu \mathrm{m})$ were processed as described above for the immunocytochemical identification of INGAP-positive cells.

\section{Smear immunocytochemistry}

Smears of pancreatic cells from the digested pancreas were fixed in $96 \%$ ethanol, and thereafter sequentially incubated with appropriate dilutions of INGAP antibody (1:600), and counterstained with haematoxylin.

\section{Isolation of total RNA}

Total RNA was separately obtained from fresh or cultured isolated islets and exocrine pancreatic tissue using guanidinium isothiocynate (Chomczynski \& Sacchi 
1987). The integrity of RNA was checked by agaroseformaldehyde gel electrophoresis (Sambrook et al. 1989), while possible contamination with protein or phenol was controlled by measuring the $260 / 280 \mathrm{~nm}$ absorbance ratio.

\section{RT-PCR}

RT-PCR was performed using the Access RT-PCR single-tube, two-enzyme system (Promega Corporation, Madison, WI, USA). The same amount of total RNA (25 ng) from both endocrine and exocrine tissue was used as template. A specific pair of primers based on the INGAP cDNA sequence in the hamster (sense primer: 5'-CAAGACAGGTACCATGATGC-3', and antisense primer: 5'-TGCTCTTCCTGAGTGAATCC-3') were used per reaction (Rafaeloff et al. 1997). Possible contamination with genomic DNA was checked in each isolation by negative controls without the avian myeloblastosis virus reverse transcriptase enzyme (Sambrook et al. 1989). A pair of primers for $\beta$-actin (sense primer: $5^{\prime}$ CGTAAAGACCTCTATGCCAA-3', and antisense primer: 5'-AGCCATGCCAAATGTCTCAT-3') were used for positive and negative controls (Mashima et al. 1996).

RT-PCR cycling conditions were: $48{ }^{\circ} \mathrm{C}$ for $45 \mathrm{~min}$; $94{ }^{\circ} \mathrm{C}$ for $2 \mathrm{~min}$; 35 cycles of $94{ }^{\circ} \mathrm{C}$ for $15 \mathrm{~s}, 60{ }^{\circ} \mathrm{C}$ for $30 \mathrm{~s}, 72{ }^{\circ} \mathrm{C}$ for $1 \mathrm{~min}$, and $72{ }^{\circ} \mathrm{C}$ for $10 \mathrm{~min}$. PCR products were separated by gel electrophoresis on a $1.5 \%$ (w/v) agarose gel. Sample identities were confirmed by sequencing on an ABI 373 A DNA sequencer system (Applied Biosystems, Foster City, CA, USA) (Sambrook et al. 1989).

\section{Results}

The Western blot analysis performed with homogenates of fresh isolated islets, exocrine cells, whole pancreas and INGAP antibody showed in all cases the presence of a single band of about $20 \mathrm{kDa}$, compatible with INGAP's molecular mass (Fig. 1).

Immunoreactive INGAP cells were observed in the three subsectors of normal hamster pancreata - duct, exocrine and islet cells - in either fixed intact or digested pancreatic tissue (Fig. 2A-E). Fewer INGAP-positive cells could be seen in digested islets than in the intact pancreas. A similar decrease was observed in the number of glucagon-positive cells in digested islets (data not shown). No stained cells were observed when the specific first antibody was replaced by normal rabbit serum (data not shown). As previously reported, the majority of these INGAP-positive cells did not react with antibody to insulin or with antibodies against the other islet hormones (Del Zotto et al. 2000).

Using the RT-PCR procedure with total RNA from either isolated islets or islet-free exocrine tissue as template,

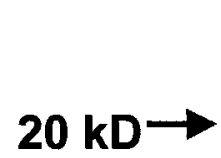

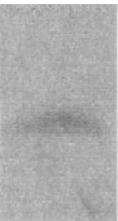

10

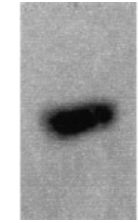

5

$\mu \mathrm{g}$ protein

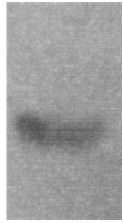

5
Figure 1 INGAP expression in the cytosolic fraction of islet cells, pancreatic exocrine cells and whole pancreas. Western blotting showed a single band of about $20 \mathrm{kDa}$ when aliquots of homogenates from isolated islets (lane 1), exocrine tissue (lane 2) and whole fresh pancreas (lane 3) were incubated with INGAP antibody. The amount of protein used is shown below each lane. In all cases, Kaleidoscope polypeptide prestained standards (BioRad) were used as molecular mass markers.

we further identified a band corresponding to INGAP cDNA in the islets and in exocrine cells (Fig. 3). The quality and purity of each one of the samples used for this analysis was checked by its immunocytochemical staining (Fig. 2B and D). Identification of this band in previously cultured islets rules out the possible contamination of the extracted material with exocrine cells attached to the isolated islets (Fig. 3). The sequencing study of this band showed $100 \%$ homology (data not shown) with the reported cDNA sequence of hamster INGAP (Gene Bank accession No: U41738) (Rafaeloff et al. 1997).

\section{Discussion}

Using different immune methods (Western blot and immunocytochemistry) and different pancreas samples (fresh whole pancreas, exocrine cells obtained by collagenase digestion and freshly isolated islets), we have currently shown the presence of INGAP protein in islets and in exocrine cells. The immunocytochemical pattern observed was similar to that previously reported in fresh whole pancreas of hamsters (Del Zotto et al. 2000) and islet neogenesis in human pancreas (Rafaeloff-Phail et al. 1998b, Semakula et al. 2002). These results and the identification of INGAP mRNA demonstrate that, at least in normal hamsters, INGAP is present and possibly synthesized in both endocrine and exocrine pancreatic cells. The previously reported failure to detect mRNA in hamster islets may be ascribed to the lower sensitivity of the in situ hybridization technique used by the authors (Rafaeloff et al. 1997), as compared with the RT-PCR currently used.

The Western blot analysis of digested tissue showed a much more intense band in exocrine cells than in isolated islets, even when half the amount of protein was used in the former than in the latter (Fig. 1). Conversely, immunocytochemical studies of intact pancreas showed a 

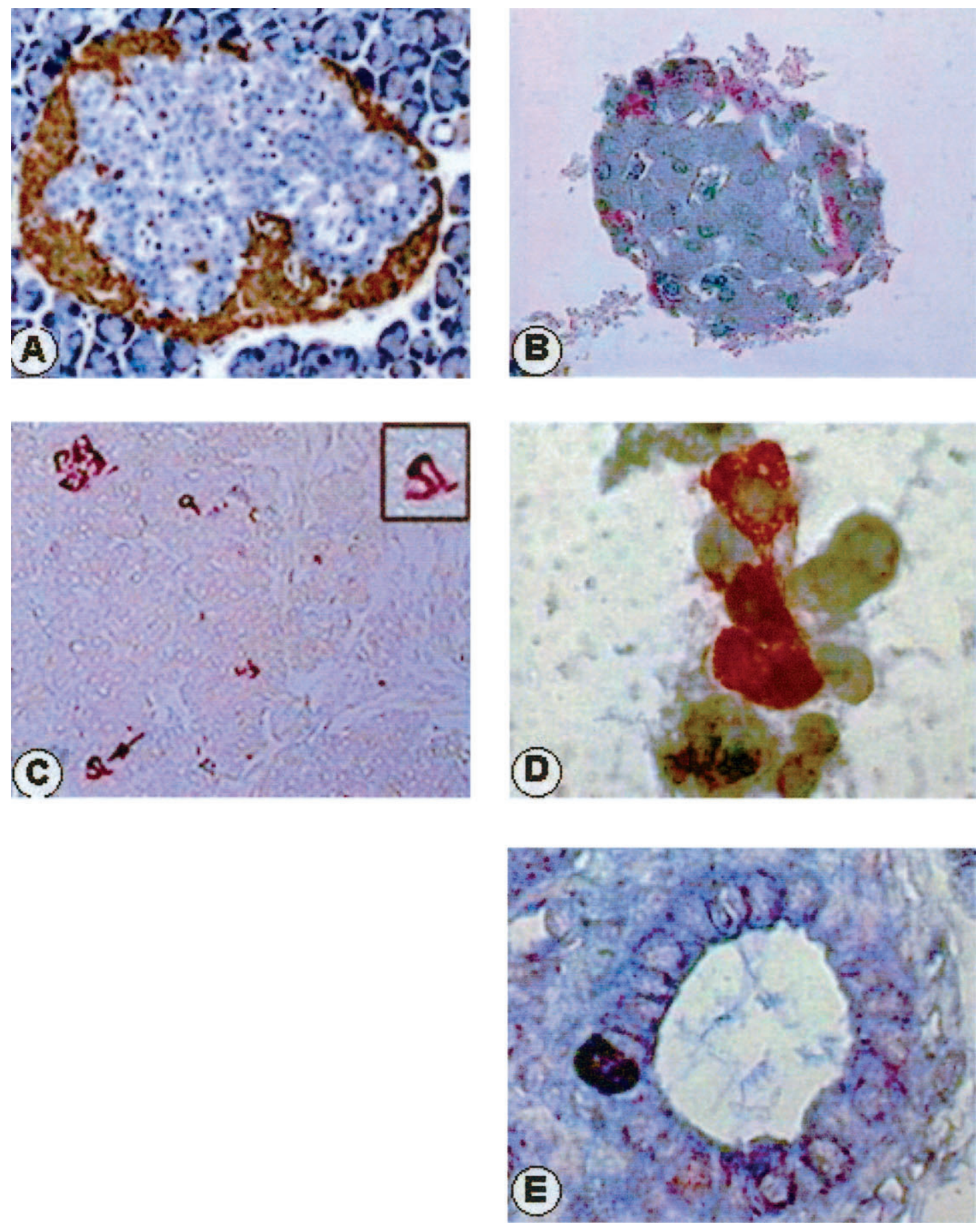

Figure 2 Immunocytochemical presence of INGAP in pancreatic cells. (A) Section of an entire fixed pancreas treated with INGAP antibody and counterstained with haematoxylin. A continuous ring of INGAP-positive cells (stained in brown (DAB reaction)) is observed at the islet periphery (non- $\beta$-cells) $(\times 200)$. (B) Section of an isolated fixed islet treated with INGAP antibody and counterstained with haematoxylin. Scarce INGAP-positive cells (stained in red by carbazole) can be seen at the islet periphery (non- $\beta$-cells) $(\times 200)$. (C) Section of an entire fixed pancreas treated with INGAP antibody. Stained cells (DAB) have a pyramidal shape with the nucleus situated at the centre, characteristic of acinar cells $(\times 100)$. Arrow shows two cells that are magnified in the inset. (D) Smears of acinar cells fixed with $96 \%$ ethanol, treated with INGAP antibody (revealed with carbazole), and counterstained with haematoxylin. Stained cells (in red) have the same characteristics as the acinar cells described in $(C)(\times 1000)$. (E) Section of an entire fixed pancreas treated with INGAP antibody. An INGAP-positive cell (stained with alkaline phosphatase and fast blue) is seen in the layer of cells of a pancreatic duct $(\times 1000)$. 

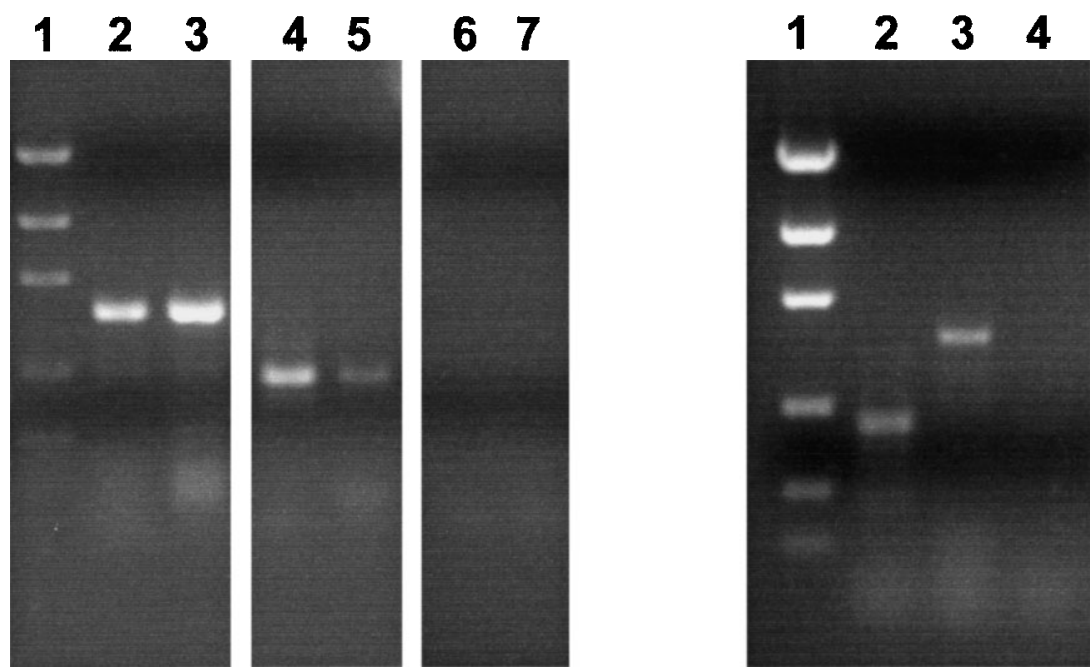

Figure 3 RT-PCR performed using total RNA extracted from homogenates of islet and exocrine tissue cells isolated by collagenase digestion (see Materials and Methods). Left panel: expression of INGAP and $\beta$-actin in freshly isolated islets (lanes 2 and 4 respectively), and in exocrine tissue (lanes 3 and 5 respectively). Negative controls for $\beta$-actin without reverse transcriptase were included (lanes 6 for islets and 7 for exocrine tissue). Right panel: expression of $\beta$-actin and INGAP in cultured islets ( $72 \mathrm{~h}$, lanes 2 and 3 respectively). A negative control for $\beta$-actin without reverse transcriptase was included (lane 4). In both panels, lane 1 corresponds to the Low DNA Mass Ladder (100, 200, 400, 800, 1200 and $2000 \mathrm{bp}$; Gibco-BRL).

larger number of INGAP-positive cells in the islets rather than in exocrine cells. The apparent discrepancies in these results may be due to the loss of cells from the islet periphery during collagenase digestion, exactly where INGAP-positive cells are located. This assumption is supported by the fewer number of INGAP- and glucagonpositive cells observed in digested islets compared with those seen in the intact pancreas (Fig. 2A and B). Such loss of INGAP-positive cells could contribute to the increased apoptosis and reduced biological effectiveness of transplanted islets (Berney et al. 2001). Thus, in order to preserve INGAP-positive cells, a gentler collagenase digestion should be used when islets are isolated for transplantation. Alternatively, even though individual islet cells contain more INGAP than acinar cells, the greater number of the latter could explain why the band from exocrine tissue in Western blots is stronger than that corresponding to the islets.

INGAP is a 175 amino acid protein with a molecular mass of $19940 \mathrm{Da}$ and an isoelectric point of $7 \cdot 86$ (Rafaeloff et al. 1997). Its amino acid sequence shows high homology with several proteins encoded by members of the Reg gene family: 58\% with rat pancreatitis associated protein (PAP)-I, 45\% with PAP-II, 50\% with PAP-III and $54 \%$ with hepatocarcinoma-intestine-pancreas protein (Rafaeloff et al. 1997). It also has high identity with the mouse Reg III- $\delta$ protein ( $72 \%$ of identities and $82 \%$ of positives). It has further been suggested that the counterpart of the mouse Reg III- $\delta$ gene exists not only in the human and rat genomes, but also in the hamster genome, and that INGAP would be the hamster Reg III- $\delta$ itself (Abe et al. 2000).

In our immunocytochemical studies we used an INGAP antibody directed against a 20 amino acid region (amino acids 20-39), having a 75\% identity (and $90 \%$ positives) with $\operatorname{Reg}$ III- $\delta$ (amino acids 21-40). Thus, it could be argued that our antibody reacted not only with INGAP but also with the Reg III- $\delta$ peptide. There are, however, some facts arguing against such an assumption, namely: (i) the $\operatorname{Reg}$ III- $\delta$ peptide is expressed predominantly in the exocrine pancreas of the mouse, but not in normal islets (Terazono et al. 1990); (ii) other members of the Reg gene family are expressed in regenerating islets, but they are exclusively seen in islet $\beta$-cells (Terazono et al. 1990); and (iii) we have consistently found that INGAP is present mainly in islet non- $\beta$-cells, and most of these INGAP-positive cells did not stain with any of the other islet hormones (Del Zotto et al. 2000). Moreover, preliminary data obtained using antibodies raised against other portions of the INGAP molecule showed that they reacted with $\beta$ - and acinar cells exclusively (H Del Zotto, unpublished observations). Thus, further evidence is needed to demonstrate whether INGAP and $\operatorname{Reg}$ III- $\delta$ are different proteins, or the same protein expressed in different cells in different animals.

In conclusion, our data demonstrate that INGAP is expressed in both endocrine and exocrine pancreatic 
cells of normal hamsters, a pattern which has also been demonstrated in islet neogenesis in humans (RafaeloffPhail et al. 1998b, Semakula et al. 2002). The ubiquitous localization of INGAP would lend support to the hypothesis of its possible role in the physiological process of islet growth, facilitating an understanding of its protective effect on streptozotocin-induced diabetes (Rafaeloff et al. 1997).

\section{Acknowledgements}

This study was supported in part by grants from FONCYT, CONICET and CICPBA. The authors are most grateful to Adrián Díaz and César Bianchi for technical assistance, and to Adriana Di Maggio for careful secretarial support.

\section{References}

Abe M, Nata K, Akiyama T, Shervani NJ, Kobayashi S, Tomioka-Kumagai T, Iso S, Takasawa S \& Okamoto H 2000 Identification of a novel Reg family gene, Reg III delta, and mapping of all three types of Reg family gene in a 75 kilobase mouse genomic region. Gene 246 111-122.

Berney T, Molano RD, Cattan P, Pileggi A, Vizzardelli C, Oliver R, Ricordi C \& Inverardi L 2001 Endotoxin-mediated delayed islet graft function is associated with increased intra-islet cytokine production and islet cell apoptosis. Transplantation 71 125-132.

Chomczynski P \& Sacchi N 1987 Single-step method of RNA isolation by acid guanidinium thiocyanate-phenol-chloroform extraction. Analytical Biochemistry 162 156-159.

Del Zotto H, Massa L, Rafaeloff R, Pittenger GL, Vinik A, Gold G, Reifel-Miller A \& Gagliardino JJ 2000 Possible relationship between changes in islet neogenesis and islet neogenesis-associated protein-positive cell mass induced by sucrose administration to normal hamsters. Journal of Endocrinology 165 725-733.
Edlund H 2001 Developmental biology of the pancreas. Diabetes $\mathbf{5 0}$ (Suppl 1) S5-S9.

Gold G, Broderick C, Carfagna M, Pittenger G, Rafaeloff R, Reifel-Miller A, Borts T, Hale J \& Churgay L 1998 INGAP treatment improves glycemic control in SZ diabetic hamsters. Diabetes 47 (Suppl 1) A253.

Lacy PE \& Kostianovsky M 1967 Method for the isolation of intact islets of Langerhans from the rat pancreas. Diabetes 16 35-39.

Mashima H, Shibata H, Mine T \& Kojima I 1996 Formation of insulin-producing cells from pancreatic acinar AR42J cells by hepatocyte growth factor. Endocrinology 137 3969-3976.

Pittenger GL, Vinik AI \& Rosenberg L 1992 The partial isolation and characterization of ilotropin, a novel islet-specific growth factor. Advances in Experimental and Medical Biology 321 123-130.

Rafaeloff R, Pittenger GL, Barlow SW, Qin XF, Yan B, Rosenberg L, Duguid WP \& Vinik AI 1997 Cloning and sequencing of the pancreatic islet neogenesis associated protein (INGAP) gene and its expression in islet neogenesis in hamsters. Journal of Clinical Investigation 99 2100-2109.

Rafaeloff-Phail R, Schmitt E, Edlund H, Gold G \& Vinik AI 1998a Expression of INGAP during ontogeny of the pancreas. Diabetes 47 (Suppl 1) A259.

Rafaeloff-Phail R, Schmitt E, Sandusky G, Rosenberg L, Gold G, Borts T, Duguid W \& Vinik AI 1998b INGAP is a human cytokine expressed only in the presence of islet neogenesis Diabetes 47 (Suppl 1) A259.

Sambrook J, Fritsch EF \& Maniatis TE 1989 Molecular Cloning: a Laboratory Manual, edn 2. Cold Spring Harbor, NY: Cold Spring Harbor Laboratory Press.

Semakula C, Pambuccian S, Gruessner R, Kendall D, Pittenger G, Vinik A \& Seaquist ER 2002 Clinical case seminar: hypoglycemia after pancreas transplantation: association with allograft nesidiodysplasia and expression of islet neogenesis-associated peptide. Journal of Clinical Endocrinology and Metabolism 87 3548-3554.

Terazono K, Uchiyama Y, Ide M, Watanabe T, Yonekura H, Yamamoto H \& Okamoto H 1990 Expression of Reg protein in rat regenerating islets and its co-localization with insulin in the beta cell secretory granules. Diabetologia 33 250-252.

Received 22 November 2002

Accepted 3 February 2003 